\title{
Coral Calcification in a Changing Ocean
}

\section{Introduction}

Animals and plants that live in the ocean form skeletons and other hard parts by combining calcium ions and carbonate ions to create calcium carbonate. This process is called calcification. In tropical and subtropical oceans, the calcification of corals and other organisms creates reefs that protect islands, produce beautiful whitesand beaches, and create habitat for thousands of species that live on coral reefs.

Many reefs around the globe are declining in health. Live, reef-building corals are becoming scarcer, often being replaced by fleshy algae (seaweeds) that do not build reefs (fig. 1). Many factors contribute to reef decline, but scientific consensus is that coral bleaching, coral disease, overfishing, and coastal development are largely to blame. It is the role of the U.S. Geological Survey (USGS) to provide science that informs the decision-making process of those who are tasked with managing reef resources under U.S. jurisdiction.

One of the goals of the Coral Reef Ecosystem Studies (CREST) project is to examine how calcification rates in reef-building corals and encrusting coralline algae are changing in response to changes in the ocean environment. Instrumental records show that the ocean is warming and getting more acidic. As carbon dioxide $\left(\mathrm{CO}_{2}\right)$ from burning of fossil fuel has accumulated in the atmosphere, about a third of it has been absorbed by the oceans. The additional $\mathrm{CO}_{2}$ in the ocean causes shifts in the chemistry of the water, resulting in a decrease in $\mathrm{pH}$ and a subsequent decrease in availability of carbonate ions. Carbonate ions are one of the two building blocks making up calcium carbonate. The less available they are, the slower many organisms are able to calcify. So far, controlled experiments have shown that some species of corals, oysters, clams, and algae calcify more slowly in $\mathrm{pH}$ conditions similar to those predicted for the end of this century (see USGS contributions to this research in "Further Reading"). Seagrasses and shrimp, however, are among the select organisms that have shown increased or stable growth rates in simulated ocean acidification experiments.

\section{USGS Study Measures Calcification in the Florida Keys}

Research under way within the CREST project at the St. Petersburg Coastal and Marine Science Center includes a network of calcificationmonitoring sites. This field study will provide baseline information on the latitudinal and seasonal variability in calcification rates for a species of reefbuilding coral and encrusting coralline algal communities. We are monitoring calcification of corals by transplanting colonies onto plastic discs, which are bolted to the top of cinderblocks fixed to the reef (fig. 2). The corals can easily be removed from the blocks for weighing using a buoyant technique whereby the corals are kept submerged in seawater. Coral-calcification monitoring stations offshore from Miami, Key Largo, Marathon, and the Dry Tortugas are co-located with the Sustained Ecological Research Related to the Management of the Florida Keys Seascape (SEAKEYS) stations that record several oceanographic variables, including temperature, light, and salinity. These data will allow us

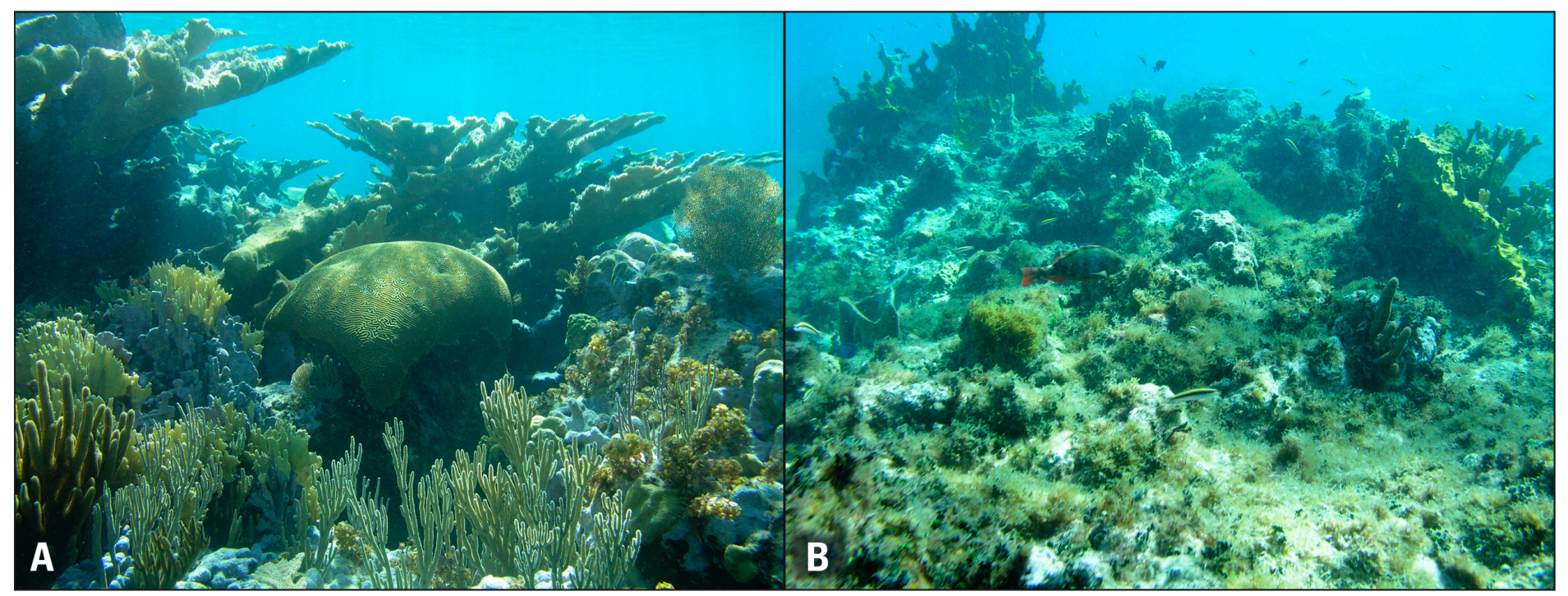

Figure 1. Coral reef habitat (A) dominated by reef-building corals (Great Exuma, Bahamas) and (B) covered with non-calcifying fleshy algae (Europa Bay, U.S. Virgin Islands). Photo credit: I.B. Kuffner. 


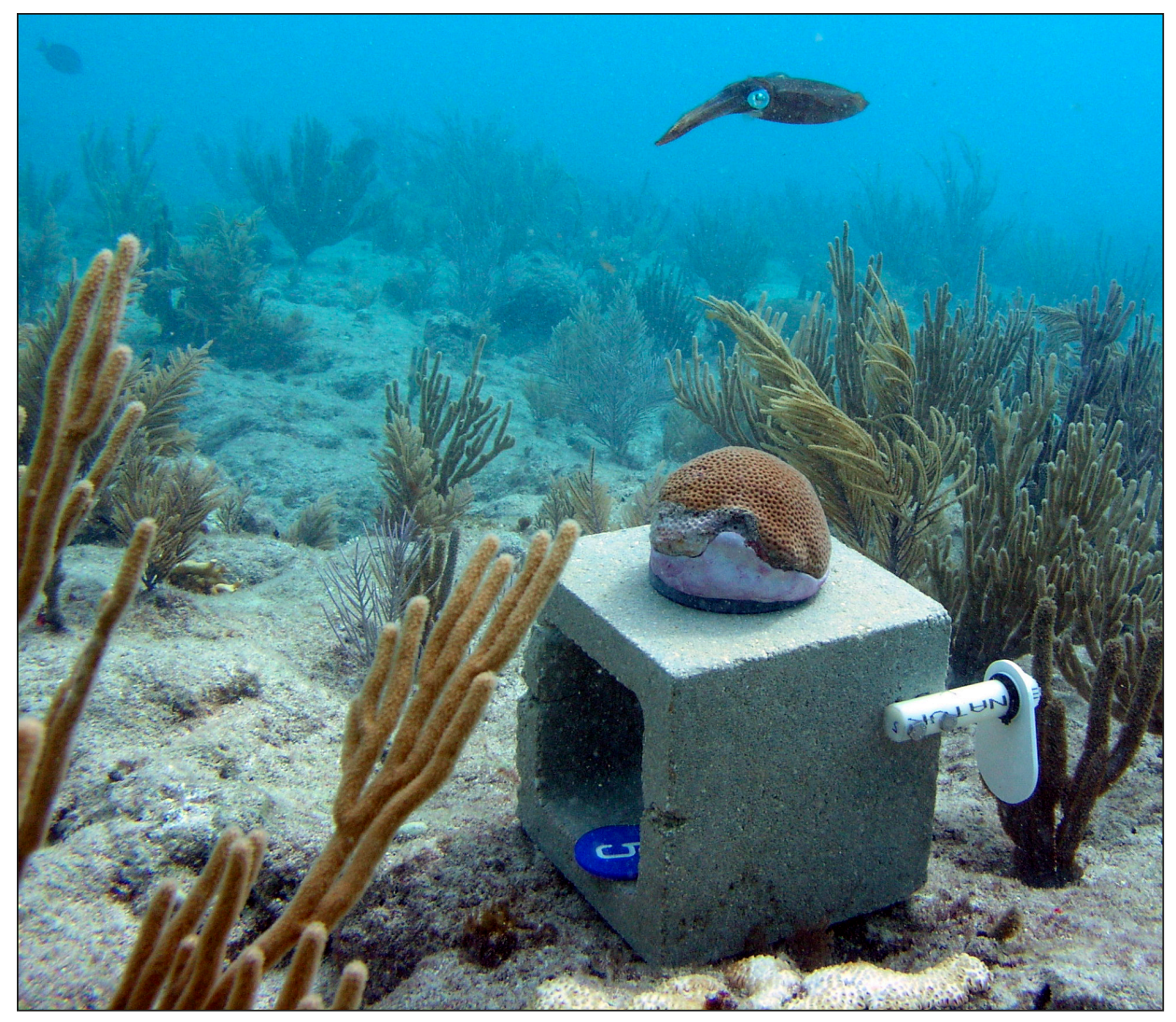

Figure 2. Calcification station at Fowey Rocks Light, off of Miami, with a curious reef squid looking on. Photo credit: T.D. Hickey.

to correlate the calcification data with seawater chemistry and temperature.

We predict that corals will show declines in growth rate within the next two decades, given current trends in ocean acidification. Response of corals to increasing temperatures, however, could be complex. Wintertime and springtime growth could actually increase, since warmer temperatures enhance calcification up until the $\sim 27^{\circ} \mathrm{C}$ temperature optimum. Summertime growth could decline if temperatures rise above the optimum and especially if temperatures reach and stay above

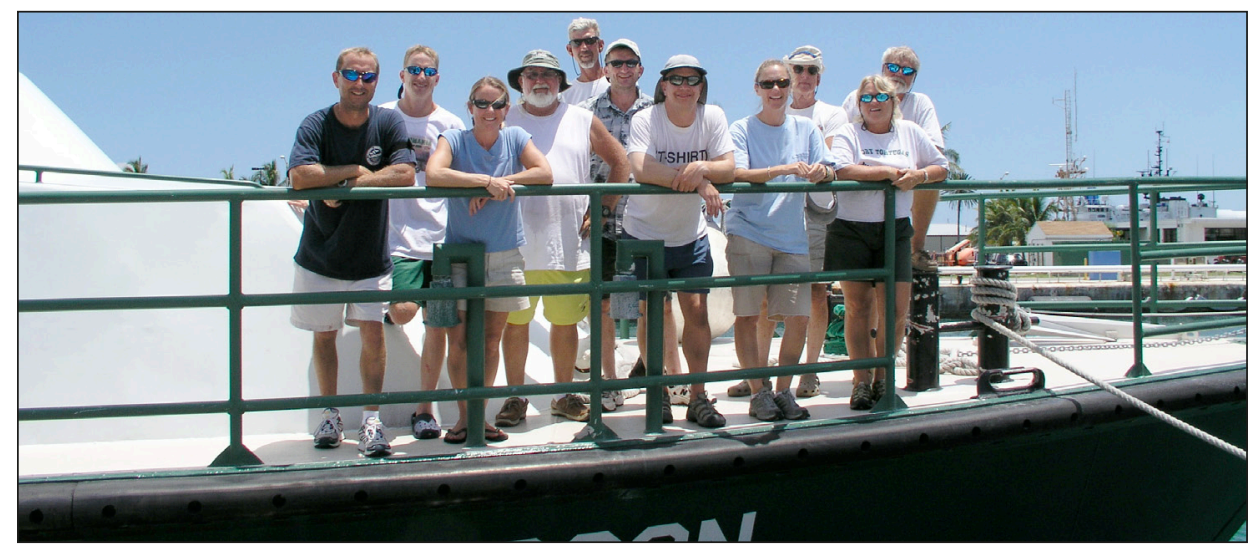

Funding for the Coral Reef Ecosystems Studies (CREST) project is provided mainly by the Coastal and Marine Geology program with some contribution from the Terrestrial, Freshwater, and Marine Ecosystems program. Initial funds to set up the calcification monitoring network were provided by the USGS Global Climate Change program. Research is greatly enhanced by the support of the National Park Service, where USGS scientists work closely with the crew of the M/V Ft. Jefferson. The logistical challenges of a research trip in such an isolated location as Dry Tortugas National Park are many, and the help of Captains Blue and Janie Douglass and First Mate John Spade is critical to accomplishing research objectives. From left to right: Don Hickey, Adam Brame, Ilsa Kuffner, Gary Hill, John Spade, Keith Ludwig, Dave Zawada, Kristen Hart, Phil Thompson, Janie Douglass, and Blue Douglass.

\section{Contact Information:}

Ilsa B. Kuffner, Ph.D.

Research Ecologist

U.S. Geological Survey

St. Petersburg Coastal and Marine Science Center 600 4th Street South

St. Petersburg, Fl 33701

PH: (727) 803-8747 x3048

Email: ikuffner@usgs.gov

\section{http://coastal.er.usgs.gov/crest/}

$30^{\circ} \mathrm{C}$ for longer than a few weeks. The high temperatures usually occur in the late summer and cause coral bleaching, wherein the symbiosis between corals and their single-celled algae (zooxanthellae) that they farm inside of their tissues breaks down and the coral appears white. Coral calcification slows or completely stops during bleaching.

\section{Conclusion}

The Florida Keys represent a northerly position in latitudinal range for many tropical species. Because of the natural gradient and seasonal fluctuation in carbonate ion availability, Florida's northern coral reefs and associated carbonate systems will likely be among the first to show signs indicating changes in ocean $\mathrm{pH}$. They already show the impacts of rising temperatures as several bleaching events have caused coral mortality throughout the reef tract. This study will contribute empirical data for making educated predictions about future coral-reef building and response to climate change. Such predictions will provide guidance for national, state, and local resource managers and policy makers as they develop management strategies for these important carbonate ecosystems.

\section{Further Reading}

Jokiel, P.L., Rodgers, K.S., Kuffner, I.B., Andersson, A.J., Cox, E.F., and Mackenzie, F.T., 2008, Ocean acidification and calcifying reef organisms: a mesocosm investigation: Coral Reefs, v. 27, no. 3, p. 473-483.

Kuffner, I.B., Andersson, A.J., Jokiel, P.L., Rodgers, K.S., and Mackenzie, F.T., 2008, Decreased abundance of crustose coralline algae due to ocean acidification: Nature Geoscience, v. 1, p. 114-117. 